\title{
Utilizing of bio-adsorbent in zero waste concept: adsorption study of crystal violet onto the centaurea solstitialis and verbascum thapsus plants
}

\section{Sıfır atık konseptinde biyo-adsorban kullanımı: kristal violet'in centaurea solstitialis ve verbascum thapsus bitkileri üzerine adsorpsiyon çalışması}

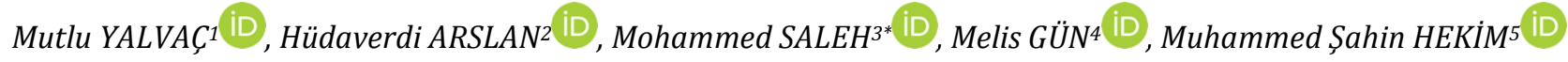 \\ 1,2,3,4,5Environmental Engineering Department, Engineering Faculty, Mersin University, Mersin, Turkey. \\ myalvac@mersin.edu.tr, harslan@mersin.edu.tr, muh.saleh89@gmail.com, melis.gun.38@gmail.com, voosha0@gmail.com
}

\begin{abstract}
Adsorption is one of the most widely used methods for dye removal from water. At the end of the adsorption process, the dyed adsorbents emerging as a second-order waste which is the main disadvantage of this process. In this study, the removal of a synthetic dye Crystal Violet (CV) from the synthetic wastewater by using Centaurea solstitialis (CS) and Verbascum Thapsus (VT) plants was studied by adsorption. At the end of the adsorption process, the reusing potential of the dyed plant was explored by measuring the dyed plant calorific values. Experimental design and modeling were performed using the surface response method (RSM). The regression coefficients for developed models were 0.86 for the CS plant and 0.95 for the VT plant. Adsorption process for CS and VT plants were fitted by Dubinin-Radushkevich isotherm, and Temkin isotherm, respectively. The two plants were pseudo-second-order, endothermic, and found to be chemically. CS plant had a capacity of $84.03 \mathrm{mg} \cdot \mathrm{g}^{-1}$ with a contact time of $85 \mathrm{~min}$. The capacity of the VT plant reached $109.89 \mathrm{mg}^{-1}$ at a contact time of 55 min. The calorific values results show increases in the calorific values for the two plants after the adsorption process. The CS plant increased from 4003.774 to $4458.059 \mathrm{Kcal}_{\mathrm{Kg}}{ }^{-1}$. Whereas the VT plant increased from 3206.028 to $4120.330 \mathrm{Kcal}_{\mathrm{Kg}} \mathrm{K}^{-1}$. These values indicate the using possibility of the two plants as solid fuel by burning the dyed plants in emission controlled industrial facilities by applying the zero-waste concept.
\end{abstract}

Keywords: Zero waste, Crystal violet, Centaurea solstitialis, Verbascum thapsus.

\section{Introduction}

With the increase in industrial activities in recent years, the amount of dyes used to color products has also increased [1]. Significant amounts of dyes are used, especially in the textile, paper, leather, paint, printing, food and plastic industries. In industries where dyes are used, the discharged wastewater resulting from the process without color removal sufficiently causes significant environmental problems. The discharged dyes affect the chemical structure of the water. Also, it disrupts the aesthetic appearance of the water and prevents the passage of light into the water body. All these have negative effects on the aquatic ecosystem [1],[2].

Following the Regulation on Water Pollution Control (RWPC) in Turkey published in the Official Gazette dated 31.2.2004, and

\section{Öz}

Adsorpsiyon, sudan boya gideriminde kullanilan en yaygin yöntemlerden biridir. Adsorpsiyon yönteminin en önemli dezavantajl, işlem sonunda ikinci bir atık olarak boyall adsorban maddelerin olusmasıdır. Bu çalısmada, adsorban olarak Senturea solstitialis (CS) ve Verbascum thapsus (VT) bitkileri kullanılarak sulu çözeltiden Crystal Violet'in (CV) uzaklaștırılması incelenmiștir. İșlem sonunda elde edilen boyalı adsorbanların kalorifik değerleri belirlenerek farklı amaçlar için kullanılabilirliği araştırılmıştır. Deneysel tasarım ve modelleme, yüzey tepki yöntemi (RSM) kullanılarak gerçekleștirilmiștir. Geliștirilen modeller için regresyon katsayıları CS bitkisi için 0.86 ve VT bitkisi için 0.95 olarak bulunmustur. Adsorpsiyon isleminde CS ve VT bitkilerinin sirasıly Dubinin-Radushkevich ve Temkin izotermine uyduğu tespit edilmiștir. Her iki bitki için de adsorpsiyon, sahte ikinci derece kinetik, endotermik ve kimyasal reaksiyon olarak gerçekleşmiştir. CS bitkisi için maksimum adsorpsiyon kapasitesi $84.03 \mathrm{mg} \cdot \mathrm{g}^{-1}$ ve temas süresi $85 \mathrm{dk}$.'dır. VT bitkisi için ise maksimum adsorpsiyon kapasitesi olan $109.89 \mathrm{mg} \mathrm{g}^{-1} \mathrm{e}$, $55 \mathrm{dk}$.'da ulaşılmıștır. Her iki bitkinin de adsorpsiyon öncesinde ve sonrasında kalorifik değerleri ölçülmüs ve adsorpsiyon işlemi sonrasında elde edilen boyalı adsorbanların kalorifik değerlerinin arttığı tespit edilmiștir. CS bitkisinde kalorifik değer 4003.774'ten 4458.059 Kcal. $\mathrm{Kg}^{-1}$ 'e yükselirken VT bitkisinde 3206.028'den 4120.330 Kcal.Kg-1'e yükselmiștir. Bu değerler, adsorpsiyon islemi sonrasında ikinci bir atık olarak ortaya çıkan boyal bitkilerin emisyon kontrollü endüstriyel tesislerde yakıt olarak kullanılabileceğini göstermiștir. İșlem bir bütün olarak ele alındığında sıfır atık hedefine ulaşmaktadır.

Anahtar kelimeler: Sifır atık, Kristal viyole, Centaurea Solstitialis, Verbascum thapsus.

numbered 25687 within the scope of the Environmental Legislation, the color parameter was added to the discharge criteria for treated wastewater with the amendment dated $24 / 4 / 2011$ and numbered 27914 . According to this regulation, the color parameter for the composite samples after $2 \mathrm{~h}$ should be $280 \mathrm{Pt}$-co and $260 \mathrm{Pt}$-co after 24h [3].

Crystal Violet (CV), also methyl violet or basic violet, is a cationic triphenylmethane dye [4]. Triphenylmethane dyes are well soluble in water since they contain sulfonic acid [5]. CV dye can be used as a pH indicator, it is used to classify gram bacteria, textiles, food additives, cosmetics, plastics, and paper prints [6],[7]. Despite its wide range of applications, CV dye is known to have toxic effects [8],[9]. For these reasons, to protect water

${ }^{*}$ Corresponding author/Yazışılan Yazar 
resources and human health, the $\mathrm{CV}$ dye should be treated before being delivered to the receiving environment [9].

There are different methods used in dye removal from water. Some of them; coagulation-flocculation [10], photocatalytic oxidation [11], reverse osmosis [12], ozonation [13], chemical oxidation [14], membrane filtration [15] and adsorption. Adsorption is a preferred method for dye removal among other advanced treatment techniques, due to its economic and environmental friendliness [7]. The limitation of this technique is the generation of the second-order contaminant.

Adsorption is the process by which molecules in one substance adhere or attach to the surface of another substance [16]. In the adsorption process, the properties of the adsorbents and the adsorbed substances are affected by factors such as $\mathrm{pH}$, temperature, presence of ions in the environment, adsorption kinetics and time [17].

Adsorbent materials are divided into two as natural and synthetic adsorbent materials. Natural adsorbents are classified as inorganic (zeolite, clay, perlite, etc.) and organic according to their structure. The most common synthetic and inorganic adsorbent is activated carbon. It has the highest adsorption capacity. Because of its costs, the researchers are investigating alternative adsorbent materials. The use of natural, organic, and inanimate adsorbents such as agricultural by-products and plant wastes as adsorbents is cheaper and environmentally friendly [18],[19].

These adsorbents are preferred because they do not dissolve in water, have a large surface area, and contain functional groups such as lignin, hydroxyl $(\mathrm{OH})$ and carboxyl $(\mathrm{COOH})$, which are connect to the dyes in wastewater and remove it from the water [20]. It is also possible to increase the adsorption capacity by replacing these functional groups with simple activation processes [21]. The only disadvantage of natural herbal adsorbent materials is that they are not suitable for every dye [22].

As mentioned above, the limitation of the adsorption process is the generation of the second-order contaminant. The dyed adsorbents remaining after the adsorption process are evaluated as hazardous wastes. These wastes cannot be disposed of in landfills, but they can be disposed of in hazardous waste disposal facilities. Hazardous waste incineration license plant is one of the possible solutions as they can be used within the scope of Waste Derived Fuel (ATY). According to Turkish Communique (2014), the wastes with the energy larger than $2500 \mathrm{kcal} / \mathrm{kg}$ will be used together as additional fuel to obtain energy in incineration plants. The communique stated that absorbents and filter materials contaminated with dangerous substances can be accepted to the facilities as ATY [23].

Response Surface Method (RSM) is a method using statistical and mathematical techniques for experimental design, model development and investigation of the effect of independent variables [24],[25]. It is important to use RSM in experimental design and modeling to reduce the use of chemicals and shorten the test times.

Centaurea solstitialis (CS) is a thorny plant observed in many parts of the world. It also found in agricultural areas in Turkey in the vacant land and arid slopes [26]. It obstacle the development and production yield of the plant grown on agricultural land. The CS plant, which is removed from agricultural lands by various means, emerges as waste with no economic value [27].
Verbascum Thapsus (VT) is a leaf hairy plant that grows in many parts of Turkey. The flower part of this plant contains essential oil and glycoside. Also, because the seeds are poisonous to fish is used in fishing. The flower part and the leaf part are generally considered to be good for some diseases such as colds and are considered to be medicinal plants by local people [28].

This study aims to investigate the CV removal possibility by CS and VT plants as low-cost bio-adsorbents from the aqueous solution. It also aims to study the potential reusing of the dyed plants in emission controlled industrial facilities to eliminate the second-order contaminants by applying the zero-waste concept.

\section{Material and method}

\subsection{Adsorbent preparation}

The CS plant was obtained from Cevttepesi of Erdemli District of Mersin Province. The VT plant was collected from the Harfilli Neighborhood of Erdemli District of Mersin Province. CS and VT plants were washed with pure water to remove dust, soil, etc. It was then dried in a HAREUS oven at $105^{\circ} \mathrm{C}$ for 24 hours. The dried adsorbents were milled with the ISOLAB blender. Based on the preliminary experiment results, the adsorbents were passed through a 35 mesh sieve (Figures 1 and 2).

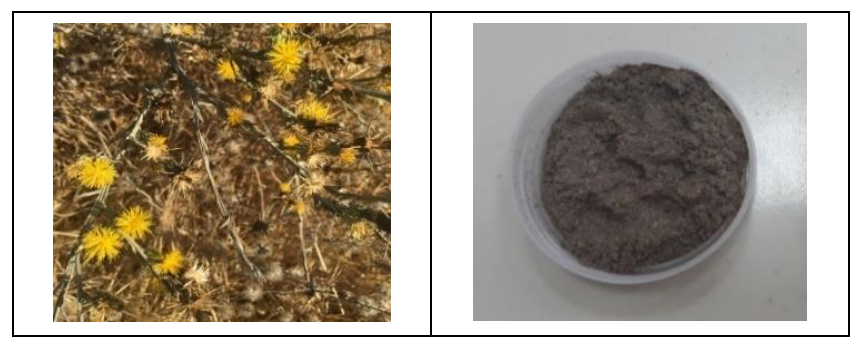

Figure 1. (a): CS plant. (b): CS adsorbent (35 mesh).

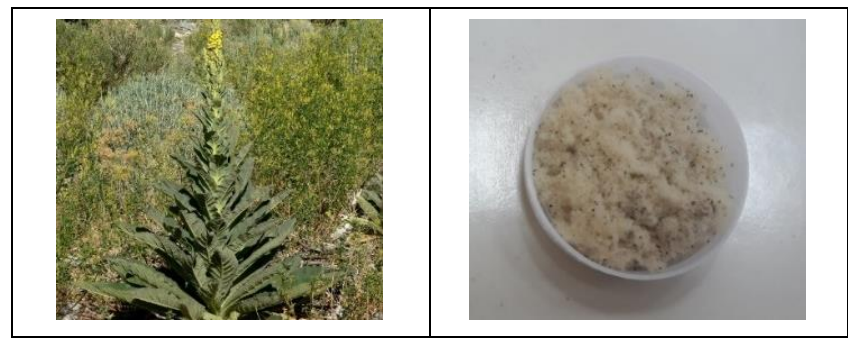

Figure 2. (a): VT plant. (b): VT adsorbent (35 mesh).

\subsection{Crystal violet preparation}

The chemical formula of the cationic $\mathrm{CV}$ dye is $\mathrm{C}_{25} \mathrm{H}_{30} \mathrm{~N}_{3} \mathrm{Cl}$ (Figure 3), with a molecular weight of 407.98 g.mol-1. $1000 \mathrm{ppm}$ CV stock solution prepared from MERCK brand dye was used in the experiments. In the experiments, $0.1 \mathrm{M} \mathrm{NaOH}$ and $0.1 \mathrm{M} \mathrm{HCl}$ were used to adjust the $\mathrm{pH}$.

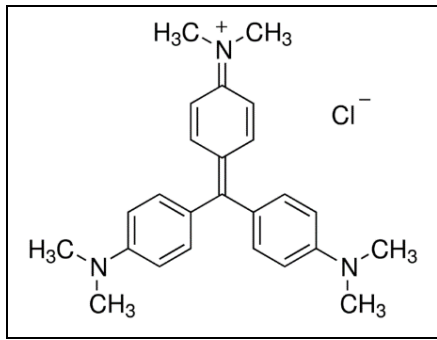

Figure 3 . The chemical structure of the CV. 


\subsection{Adsorbent Characterization}

In this study, the weights were measured by ISOLAB precision balance. MICRO TEST-ELECTROFOREST shaking incubator was used to mix the solutions at definite temperatures and $150 \mathrm{rpm}$. ISOLAB pH meter was used for acid-base determination. UV spectrophotometer (HACK DR-3900) was used to determine the color change in the experiments at $585 \mathrm{~nm}$ wavelength. Fourier Transform Infrared Spectroscopy (FTIR) was used to measure the infrared spectra of adsorbents (CS and VT). The surface area determinations were carried by Brunauer, Emmett, and Teller (BET). Scanning Electron Microscopy (SEM) (Gemini Zeiss Supra 55) devices were used to determine surface morphology.

\subsection{Adsorption experiments}

In the adsorption experiments; $\mathrm{pH}$, adsorbent mass, initial concentration of crystal violet, temperature and the contact time were optimized. $100 \mathrm{~mL}$ solution volume was used. The solutions were placed in $250 \mathrm{~mL}$ flasks in case of overflow during agitation. After the experiment, efficiency (\%) and adsorbent capacity (qe) (mg.g-1) were calculated using Equation 1 and Equation 2, respectively [29].

$$
\begin{gathered}
\text { Efficiency } \%=\frac{\left(C_{i}-C_{f}\right)}{C_{i}} \times 100 \\
q_{e}=\frac{\left(C_{i}-C_{f}\right) \times V}{m}
\end{gathered}
$$

Where, $\mathrm{Ci}$ is the initial concentration (mg. $\left.\mathrm{L}^{-1}\right)$ of the $\mathrm{CV}$ dye; $\mathrm{Cf}$ is the CV final concentration (mg. $\mathrm{L}^{-1}$ ); V solution volume (L); $\mathrm{m}$ indicates the adsorbent mass (g).

Desorption process was carried out as shown in the previous studies [27],[29] with some modification. The dyed adsorbent obtained at the end of the adsorption process was shaken with $0.1 \mathrm{M} \mathrm{HCl}$ and $0.1 \mathrm{M} \mathrm{NaOH}$ solutions at $150 \mathrm{rpm}$ for 24 hours to calculate the percentage of recovery (desorption). The recovery percentage was calculated using Equation 3:

$$
\text { Recovery } \%=\frac{\text { Desorption Concentration }}{\text { Adsorbed Dye Concentration }} \times 100
$$

\subsection{Adsorption isotherms}

To explain the relationship between adsorbent and adsorbed substance; Langmuir [30], Freundlich [31], Temkin [32] and Dubinin-Radushkevich (D-R) isotherms were used [27],[32]. Langmuir isotherm is based on the assumption of single-layer adsorption on the homogeneous surface of the adsorbent (Equation 4) [30]. Freundlich isotherm refers to an empirical equation in the adsorption process (Equation 5) [31]. Temkin isotherm explains the adsorption mechanism by energy distribution (Equation 6) [32]. Dubinin-Radushkevich (D-R) isotherm explains the distribution of Gaussian energy on a heterogeneous surface [27]. Furthermore, D-R isotherm is related to the porous structure of the adsorbent and provides information about the physical or chemical adsorption process (Equation 7). If the term [RTLn $\left.\left(1+\frac{1}{C_{A}}\right)\right]^{2}$ has a value higher than $8 \mathrm{~kJ} \cdot \mathrm{mol}^{-1}$, the adsorption occurs chemically [33].

$$
\frac{\mathrm{C}_{\mathrm{A}}}{\mathrm{q}_{\mathrm{A}}}=\frac{1}{\mathrm{~b}_{\mathrm{A}} \mathrm{q}_{\mathrm{m}}}+\frac{\mathrm{C}_{\mathrm{A}}}{\mathrm{q}_{\mathrm{m}}}
$$

$$
\begin{gathered}
\log \left(\mathrm{q}_{\mathrm{A}}\right)=\log \left(\mathrm{K}_{\mathrm{A}}\right)+\left(\frac{1}{\mathrm{n}}\right) \log \left(\mathrm{C}_{\mathrm{A}}\right) \\
\mathrm{q}_{\mathrm{A}}=\frac{\mathrm{RT}}{\mathrm{b}_{\mathrm{T}}} \operatorname{LnA}_{\mathrm{T}}+\frac{\mathrm{RT}}{\mathrm{b}_{\mathrm{T}}} \ln \mathrm{C}_{\mathrm{A}} \\
\mathrm{Lnq}_{\mathrm{A}}=\mathrm{Lnq}_{\mathrm{s}}-\mathrm{K}_{\mathrm{ad}}\left[\operatorname{RTLn}\left(1+\frac{1}{\mathrm{C}_{\mathrm{A}}}\right)\right]^{2}
\end{gathered}
$$

Where $\mathrm{C}_{\mathrm{A}}$ is the concentration of adsorbate $\mathrm{A}$ at the equilibrium (mg.L-1 ${ }^{-1}$. $\mathrm{b}_{\mathrm{A}}$ is Langmuir constant for the adsorbate A (L.mg-1). $\mathrm{Q}_{\mathrm{M}}$ maximum adsorbent capacity at saturation (mg.g-1). $\mathrm{K}_{\mathrm{A}}$ is Freundlich adsorption capacity parameter (mg.g-1) (L.mg-1). $1 / \mathrm{n}$ is the intensity parameter. $\mathrm{R}$ is the universal gas constant (8.314J. $\left.\mathrm{K}^{-1} \cdot \mathrm{M}^{-1}\right)$. $\mathrm{T}$ is the absolute temperature. $\mathrm{b}_{\mathrm{T}}$ is Temkin isotherm constant. $\mathrm{A}_{\mathrm{T}}$ is the binding constant ( $\mathrm{L.g}^{-1}$ ). $\mathrm{q}_{\mathrm{s}}$ is the theoretical saturation capacity (mg. $\left.\mathrm{g}^{-1}\right)$. Kad is the isotherm constant $\left(\mathrm{mol}^{2} \cdot \mathrm{kJ}^{-2}\right)$.

\subsection{Adsorption kinetics}

Adsorption kinetic models have been used to express the behavior of the adsorption reaction. Also, the models describe the mechanism by which the adsorbent substance interacts with the adsorbed substance [17],[32]. The linear forms of the pseudo-first-order kinetic model [34] and pseudo-secondorder kinetic model [35] are shown in Equation 8 and Equation 9 respectively.

$$
\begin{gathered}
\log \left(\mathrm{q}_{\mathrm{e}}-\mathrm{q}_{\mathrm{t}}\right)=\log \mathrm{q}_{\mathrm{e}}-\frac{\mathrm{K}_{1}}{2.303} \mathrm{t} \\
\frac{t}{q_{t}}=\frac{1}{K_{2} q_{e}^{2}}+\frac{1}{q_{e}} t
\end{gathered}
$$

In the equations; qe is the amount of adsorbed material in equilibrium; qt, is the amount of adsorbed material at the end of time $\mathrm{t} ; \mathrm{K}_{1}$ represents the first-order rate constant $\left(\mathrm{min}^{-1}\right)$ of adsorption and $\mathrm{K}_{2}$ shows the false second-order rate constant (g.mg-1.h-1).

\subsection{Adsorption thermodynamics}

To examine the Adsorption thermodynamics, enthalpy $(\Delta \mathrm{H})$, entropy $(\Delta S)$, and Gibbs free energy $(\Delta G)$ were determined according to Equation (10-12) [36].

$$
\begin{gathered}
\Delta \mathrm{H}=-\mathrm{R}\left(\frac{\mathrm{T}_{2} \mathrm{~T}_{\mathrm{i}}}{\mathrm{T}_{2}-\mathrm{T}_{1}}\right) \operatorname{Ln} \frac{\mathrm{b}_{2}}{\mathrm{~b}_{1}} \\
\Delta \mathrm{s}=\frac{\Delta \mathrm{H}-\Delta \mathrm{G}}{\mathrm{T}} \\
\Delta \mathrm{G}=-\mathrm{RTLnb}
\end{gathered}
$$

In the equations; $\Delta \mathrm{H}$ is the enthalpy change (kJ. mol-1); $\Delta S$ is the entropy change $\left(\mathrm{kJ} \cdot \mathrm{mol}^{-1}{ }^{\circ} \mathrm{K}^{-1}\right) ; \Delta \mathrm{G}$ is the Gibbs free energy change (kJ.mol-1); R is the gas constant $\left(8.314 \mathrm{~J}^{\circ}{ }^{\mathrm{O}} \mathrm{K}^{-1} \cdot \mathrm{mol}^{-1}\right)$; T indicates temperature $\left({ }^{\circ} \mathrm{K}\right)$ and $\mathrm{b}$ indicates Langmuir constant $\left(\mathrm{mg}^{-1}\right)$.

\subsection{Response surface method (RSM)}

RSM is a modeling technique derived from a group of mathematical and statistical data based on experimental data [37]. In these experiments, the ranges of $\mathrm{pH}, \mathrm{CS}$ and VT masses, $\mathrm{CV}$ concentration, contact time, and temperature were determined. A model was created by Design Expert v11 program. The ranges of the parameters are shown in Table 1. 
Table 1. Parameters limit values.

\begin{tabular}{ccccc}
\hline & Parameter & Unit & Low & High \\
\hline $\mathrm{A}$ & $\mathrm{pH}$ & - & 5 & 8 \\
$\mathrm{~B}$ & Mass & $\mathrm{G}$ & 0.5 & 1 \\
$\mathrm{C}$ & Time & $\mathrm{min}$ & 35 & 85 \\
$\mathrm{D}$ & $\mathrm{CV}$ concentration & $\mathrm{mg} \cdot \mathrm{L}^{-1}$ & 250 & 500 \\
$\mathrm{E}$ & Temperature & ${ }^{\circ} \mathrm{C}$ & 36 & 53 \\
\hline
\end{tabular}

\subsection{The changes in the calorific values of the adsorbents}

The utilizing of the bio-adsorbents in the zero waste concept was assessed by study the reusing potentiality of the bio adsorbents as solid fuel for the emission controlled industrial facilities. The calorific value for the two plants were measured by CKIC 5E-C5500 calorimeter. To study the adsorption effects on the calorific values for the two plants, the calorific values were measured before and after the adsorption process. The change in the calorific values were notices and recorded.

\section{Result and discussion}

\subsection{Adsorbent characterization}

In this study, the surface areas for CS and VT plants were determined by BET analysis. The surface area decreased for both plants after the adsorption process. BET and Langmuir surface areas of both plants decreased after adsorption (Table 2).

Table 2. BET and Langmuir surface areas of CS and VT plants in raw and dyed form.

\begin{tabular}{ccccc}
\hline & \multicolumn{2}{c}{ CS Plan } & \multicolumn{2}{c}{ VT Plant } \\
\cline { 2 - 5 } & Raw & Dyed & Raw & Dyed \\
\hline BET Surface Area $\left(\mathrm{m}^{2} \cdot \mathrm{g}^{-1}\right)$ & 4.97 & 0.68 & 4.84 & 2.29 \\
Langmuir Surface Area $\left(\mathrm{m}^{2} \cdot \mathrm{g}^{-1}\right)$ & 6.91 & 0.81 & 6.33 & 2.94 \\
\hline
\end{tabular}

Surface morphologies for two plants were obtained by SEM analysis. Figure 4 shows the adsorbent morphology before and after the adsorption process.

The FTIR analysis shows a shıftıng in the peaks. It also shows change in the intensity of those peaks. This can support the occurrences of the adsorption process. By comparison between the graphs before and after the adoption process, many peaks disappeared at the end of the adsorption process (Figures 5 and 6).

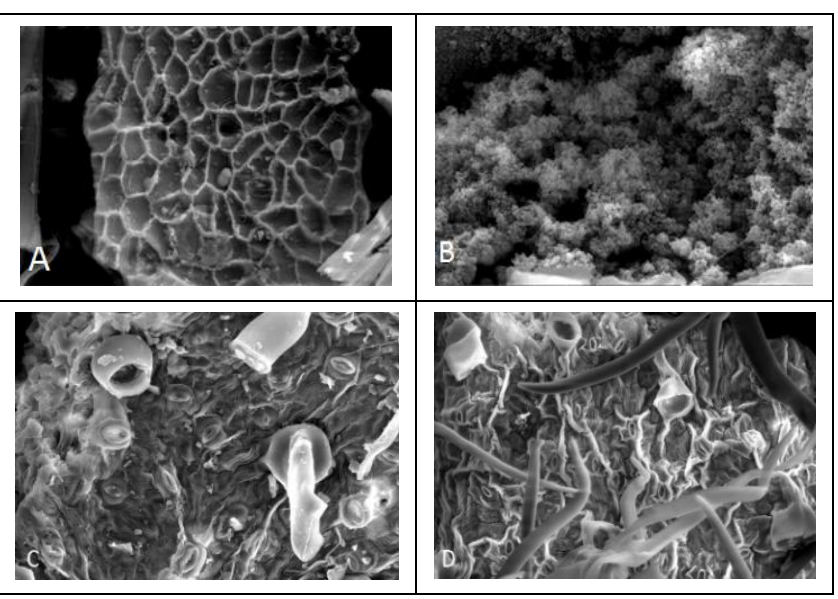

Figure 4. (a): CS before adsorption. (b): CS after adsorption. (c): VT before adsorption. (d): VT after adsorption.

In CS plant, peaks at bands of 490.79, 536.11, 1317.14, and $1603.52 \mathrm{~cm}^{-1}$ were not recorded after the adsorption process. In contrast, many new peaks were noticed. The peak at the band of $2328 \mathrm{~cm}^{-1}$ shows $\mathrm{C} \equiv \mathrm{N}$ starch bond. $\mathrm{C}-\mathrm{H}$ bend bond was recorded at the peak of $1455 \mathrm{~cm}^{-1}$. N-O asymmetric stretch bond at $1506 \mathrm{~cm}^{-1}$ was detected. In addition to that, a new peak at $1584 \mathrm{~cm}^{-1}$ shows a possible N-H bend bond formation. C-CL bond was also noticed at the band of $828.28 \mathrm{~cm}^{-1}$. The formation of new peaks gives a hint about the type of adsorption.

In the VT plant, new peaks were not be recorded. By contrast, many peaks have been shown in the raw VT and have not been recorded after the adsorption process. The following peaks bands are examples on this phenomena 471.51, 504.29, 532.26, 593.00, 895.77, 1316.18, 1453.10, 1505.17, 2319.95 and $2850.27 \mathrm{~cm}^{-1}$. This change in the chemical bonds also gives a hint about the type of the adsorption type. It also can be considered a chemical adsorption.

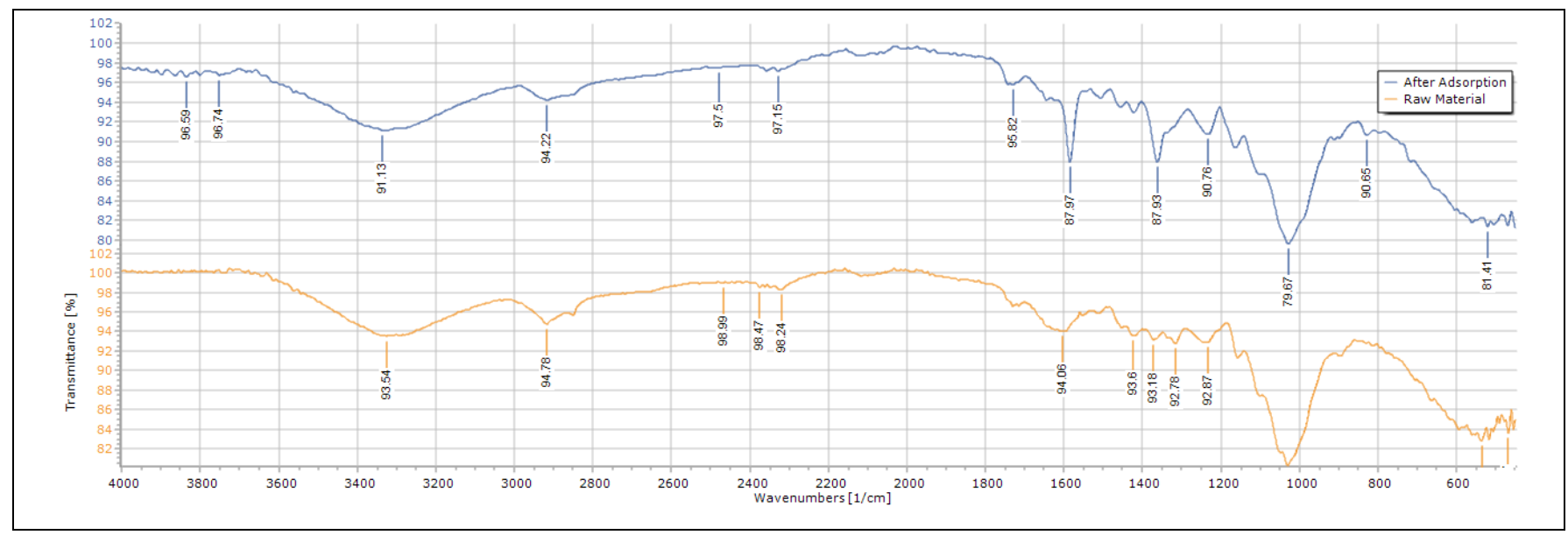

Figure 5. FTIR analysis for CS before adsorption and after adsorption. 


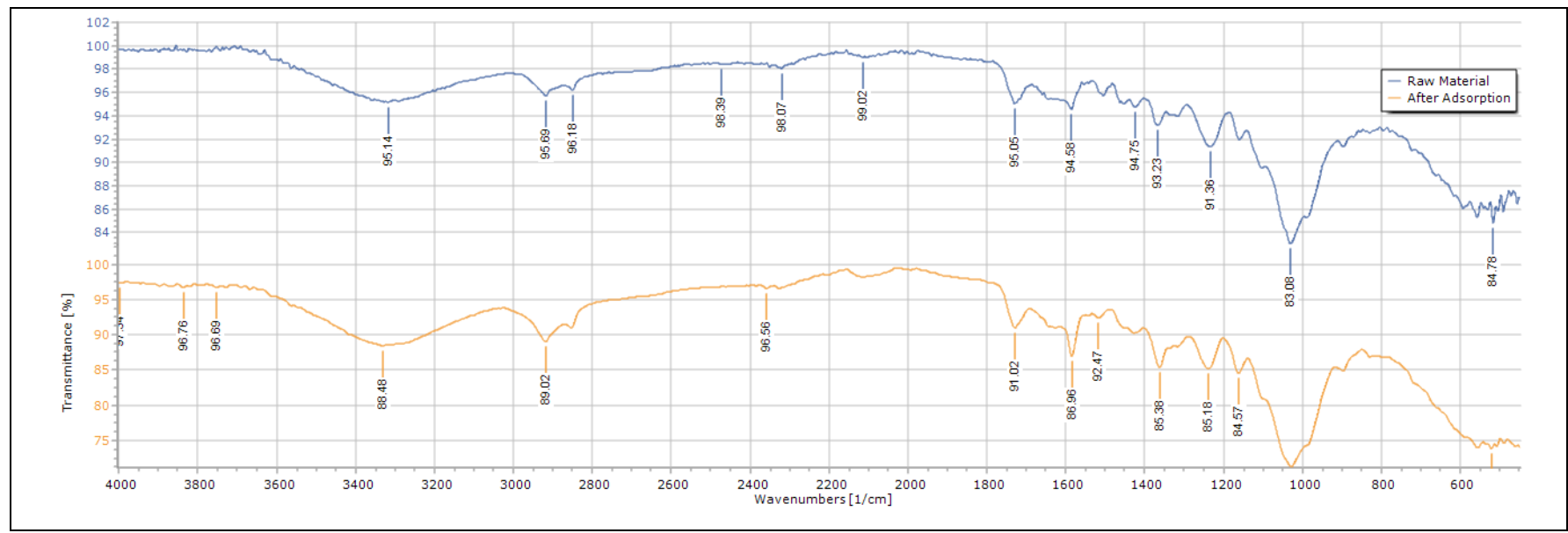

Figure 6. FTIR analysis for VT before adsorption and after adsorption.

\subsection{RSM results}

The developed models for the $\mathrm{CV}$ adsorption onto the adsorbents (CS and VT) were established by RSM. The two models were tested statistically and founded to be significant. No transformation needed for the CS plant, while a square root transformation was used for the VT plant. According to the sequential model sum of squares tests, the 2FI model and quadratic model were the most appropriate for CS plant and VT plant respectively. Appendix A1 and A2 show the sequential model sum of squares tests results for both plants. Based on these tests the correlation coefficients for the developed modes were 0.86 for CS plant and 0.95 for the VT plant.

The developed models were analyzed by analysis of variance ANOVA tests. The two models were founded to be significant. The F-values for developed models based on the removal of CV by CS plant and VT plant were 20.79 and 46.69 . There is only $0.01 \%$ for these values to occur due to noise. The ANOVA tests for the models are presented in Appendix B1 and B2. The adsorbent capacity of CV onto CS and VT can be predicted by equations 13 and 14, respectively.

$$
\begin{aligned}
\text { Capacity }=34.331 & -6.345 p H+40.852 \text { Mass } \\
& +0.224 \text { Time }+0.034 \text { Concentration } \\
& -0.601 \text { Temperature }+1.586 p H \\
& * \text { Mass }+0.008 p H * \text { Time }-0.003 p H \\
& * \text { Concentartion }+0.128 p H \\
& * \text { Temperature }-0.141 \text { Mass } * \text { Time } \\
& -0.099 \text { Mass } * \text { Concentration } \\
& -1.052 \text { Mass } * \text { Temperature } \\
& -0.0002 \text { Time } * \text { Concentration } \\
& -0.004 \text { Time } * \text { Temperature } \\
& +0.003 \text { Comcentration } \\
& * \text { Temperature }
\end{aligned}
$$

sqrt (capacity +55$)$

$$
\begin{aligned}
& =9.085+0.149 \mathrm{pH}-3.545 \mathrm{Mass} \\
& +0.031 \text { Time }+0.007 \text { Concentration } \\
& -0.041 \text { Temperature }+0.008 \mathrm{pH} \\
& \text { * Temperature - 0.005Mass } \\
& \text { * Concentration }-0.030 \mathrm{pH}^{2} \\
& +3.208 \text { Mass }^{2}-0.0002 \text { Time }^{2}
\end{aligned}
$$


The effect of temperature on the adsorption process was examined. In CS plant the capacity has increased sharply with temperature. VT plant capacity had also increased with temperature but with more flat trend. The temperature effects are shown in Figure 9.
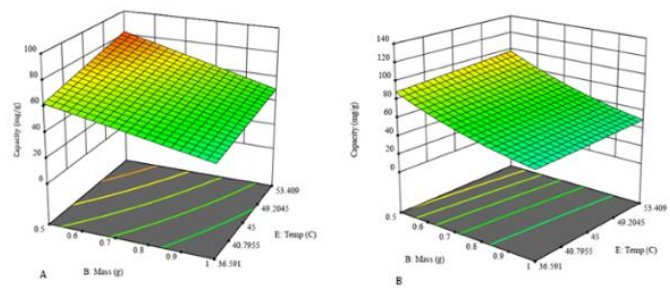

Figure 9. Adsorbent mass and the temperature effects on the capacity for. (a): CS plant. (b): VT plant.

\subsection{Adsorption isotherm}

In this study, Langmuir, Freundlich, Temkin, and DubininRadushkevich (D-R) isotherms were examined. Isotherm coefficients and regression coefficient results are given in Table 3. For the CS plant, the D-R isotherm had a higher regression value $(R=0.9906)$ than the other isotherms. The adsorption expected to occur chemically, because the value of [RT Ln $\left.\left(1+\left(1 / \mathrm{C}_{\mathrm{A}}\right)\right)\right]^{2}\left(23.57 \mathrm{~kJ} \cdot \mathrm{mol}^{-1}\right)$ is higher than $8 \mathrm{~kJ} \cdot \mathrm{mol}^{-1}$. For the VT plant, Temkin isotherm had the best fit with a regression value of 0.9221 .

Table 3. Isotherm coefficients and regression coefficients.

\begin{tabular}{|c|c|c|c|}
\hline Isotherm & & CS Plant & VT Plant \\
\hline \multirow{3}{*}{ Langmuir } & $\mathrm{q}_{\mathrm{m}}\left(\mathrm{mg} \cdot \mathrm{g}^{-1}\right)$ & 113.63 & 96.153 \\
\hline & $\mathrm{b}_{\mathrm{A}}\left(\mathrm{L} \cdot \mathrm{mg}^{-1}\right)$ & 0.0035 & -0.006 \\
\hline & $\mathrm{R}^{2}$ & 0.8672 & 0.5072 \\
\hline \multirow{3}{*}{ Freundlich } & $1 / \mathrm{n}$ & 0.691 & 1.5755 \\
\hline & $\mathrm{K}_{\mathrm{A}}\left(\mathrm{mg} \cdot \mathrm{g}^{-1}\right)\left(\mathrm{L} \cdot \mathrm{mg}^{-1}\right)^{1 / n}$ & 1.226 & 0.0913 \\
\hline & $\mathrm{R}^{2}$ & 0.9604 & 0.8965 \\
\hline \multirow{3}{*}{ Temkin } & $\mathrm{A}_{\mathrm{T}}\left(\mathrm{L} \cdot \mathrm{g}^{-1}\right)$ & -3.418 & 0.0327 \\
\hline & $\mathrm{b}_{\mathrm{T}}$ & 105.93 & 30.335 \\
\hline & $\mathrm{R}^{2}$ & 0.9764 & 0.9221 \\
\hline \multirow{3}{*}{$(D-R)$} & $\mathrm{K}_{\mathrm{ad}}\left(\mathrm{mol}^{2} \cdot \mathrm{kJ}^{-2}\right)$ & 0.0009 & 0.0004 \\
\hline & $\mathrm{q}_{\mathrm{s}}\left(\mathrm{mg} \cdot \mathrm{g}^{-1}\right)$ & 51.48 & 124.536 \\
\hline & $\mathrm{R}^{2}$ & 0.9906 & 0.9185 \\
\hline
\end{tabular}

\subsection{Adsorption kinetics}

In this study, pseudo-first-order and pseudo-second-order kinetics were examined. The kinetics coefficient results are given in Table 4 .

Table 4. Kinetics coefficients and regression coefficients.

\begin{tabular}{cccc}
\hline Kinetic & Parameter & CS Plant & VT Plant \\
\hline Pseudo-first- & $\mathrm{R}^{2}$ & 0.9942 & 0.9943 \\
order & $\mathrm{K}_{1}\left(\mathrm{~min}^{-1}\right)$ & 0.0262 & 0.052 \\
& $\mathrm{q}_{\mathrm{e}}\left(\mathrm{mg}^{-1} \mathrm{~g}^{-1}\right)$ & 20.469 & 72.227 \\
Pseudo- & $\mathrm{R}^{2}$ & 0.9998 & 0.9999 \\
second-order & $\mathrm{K}_{2}\left(\mathrm{~g}^{\mathrm{m}} \mathrm{mg}^{-1} \cdot \mathrm{min}^{-1}\right)$ & 0.0025 & 0.0009 \\
& $\mathrm{q}_{\mathrm{e}}\left(\mathrm{mg}^{-1}\right)$ & 84.033 & 109.89 \\
\hline
\end{tabular}

The regression coefficients of CS and VT plants were 0.9942 and 0.9943; pseudo-second-order kinetics are 0.9998 and 0.9999 , respectively. According to these results, the adsorption kinetics of both plants were found to be suitable for pseudo-secondorder kinetics (Table 4). The Kinetic results explain the absence of chemical and physical equilibrium. It also states that there are two reactions. The first is faster and reaches the equilibrium state faster, the second one is slow reaction and reaches the equilibrium state in a long time.

\subsection{Adsorption thermodynamics}

In this study, enthalpy $(\Delta \mathrm{H})$, entropy $(\Delta \mathrm{S})$, and Gibbs free energy $(\Delta \mathrm{G})$ were studied for the CS and VT plants. The results are given in Table 5 .

Table 5. Adsorption thermodynamics.

\begin{tabular}{cccccccc}
\hline & \multicolumn{3}{c}{ CS Plant } & \multicolumn{3}{c}{ VT Plant } \\
\hline $\begin{array}{c}\text { Temperature } \\
\left({ }^{\circ} \mathrm{K}\right)\end{array}$ & $\Delta \mathrm{G}$ & & \multicolumn{5}{c}{$\Delta \mathrm{G}$} \\
$\left(\mathrm{KJ}^{\circ} \mathrm{mol}^{-1}\right)$ & $\Delta \mathrm{H}$ & $\Delta \mathrm{S}$ & $\left(\mathrm{KJ}^{\prime} \cdot \mathrm{mol}^{-1}\right)$ & $\Delta \mathrm{H}$ & $\Delta \mathrm{S}$ \\
\hline 310 & -15.54 & 4.6 & 0.07 & -14.65 & & \\
319 & -16.11 & 2 & & -15.54 & 15. & 0.10 \\
325 & -15.54 & & & -16.11 & 50 & \\
\hline
\end{tabular}

In both plants;

- The adsorption event occurs spontaneously since the Gibbs free energy $(\Delta G)$ was found to be negative for all temperatures,

- The positive values of the Enthalpy $(\Delta \mathrm{H})$ indicate that the adsorption is the endothermic reaction,

- $\quad$ Entropy values $(\Delta \mathrm{S})$ were positive. This indicates that there may be structural changes between CS and VT plants and CV dye.

\subsection{Desorption}

Desorption experiments were carried out as a result of adsorption experiments. The plants with dye were shaken in $0.1 \mathrm{M} \mathrm{HCl}$ and $0.1 \mathrm{M} \mathrm{NaOH}$ solutions at $150 \mathrm{rpm}$ in the shaker for 24 hours. The maximum desorption yield was obtained by the interaction of both plants with acid for 120 minutes. Desorption percentages for the CS plant and VT plant were $0.76 \%$ and $1.88 \%$, respectively. According to the results, the adsorption process was considered to be chemical because there was no dye recovery.

\subsection{Zero waste concept utilization}

The zero waste concept was successfully applied in this study. The second order contaminants from the adsorption process were planned to be reused as solid fuel in emission controlled industrial facilities. To achieve that, the calorific values were measured and recorded as shown in Table 6.

The results show increases in the calorific values for the two plants after the adsorption process. The CS plant increased from $4003.774 \mathrm{Kcal}_{\mathrm{Kg}}{ }^{-1}$ to $4458.059 \mathrm{Kcal}_{\mathrm{Kg}}{ }^{-1}$, whereas, the VT plant increased from $3206.028 \mathrm{Kcal}_{\mathrm{Kg}}{ }^{-1}$ to $4120.330 \mathrm{Kcal.Kg}{ }^{-1}$. even though the calorific values for the CS plant is higher than the VT plant, the changes in the calorific values for the VT plant was notable. These values indicates the possibility to use the two plants in the solid fuel sector. 
Table 6. Calorific values for raw and dyed plants.

\begin{tabular}{cccccc}
\hline Plant & Weight $(\mathrm{g})$ & Temperature Rise $\left({ }^{\circ} \mathrm{K}\right)$ & C-Coefficient $\left({ }^{\circ} \mathrm{K}\right)$ & Heat Capacity $\left(\mathrm{J}^{\circ} \mathrm{K}^{-1}\right)$ & Calorific Values $\left(\mathrm{Kcal}^{\left.-\mathrm{Kg}^{-1}\right)}\right.$ \\
\hline CS- Raw & 1.0945 & 1.8469 & 0.0212 & 9848 & 4003.774 \\
CS- Dyed & 1.1692 & 2.1970 & 0.0241 & 9848 & 4458.059 \\
VT- Raw & 1.1227 & 1.5200 & 0.0153 & 9848 & 3206.028 \\
VT- Dyed & 1.1703 & 2.0337 & 0.0214 & 9848 & 4120.330 \\
\hline
\end{tabular}

\subsection{Comparison with other studies}

The interaction of CV dye with other adsorbent substances has been studied by many researchers. Khan et al (2016) used tea dust as a bio adsorbent to remove CV from aqueous solution with maximum adsorption capacity of $175.4 \mathrm{mg}^{-\mathrm{g}^{-1}}$ [38]. Mittal et al (2010) deploy the waste generated from the soya bean industry as low cost to remove CV. The maximum recovery of the dye was 95\% [39]. Azolla and Fig Leaves Modified with Magnetite Iron Oxide Nanoparticles were used as adsorbent for CV removal with a maximum capacity of $30.21 \mathrm{mg}^{-1} \mathrm{~g}^{-1}$ for Azolla and $53.47 \mathrm{mg}^{-1} \mathrm{~g}^{-1}$ for Fig Leaves [40]. The adsorption of CV onto a natural clay mineral from aqueous solution between 293.15 and $323.15 \mathrm{~K}$ was implemented [41]. Kulkarni et al (2017) founded the adsorption capacity of CV onto water hyacinth to be 322.58 mg.g $^{-1}$ [42]. Table 7 shows some of these studies.

Even though the adsorption capacity stated in this study is relatively smaller than the literature studies, both plants show a high removal efficiency of $\mathrm{CV}$ from aqueous solution. In addition to that the capacity is larger than the powdered activated carbon (PAC) and Afsin-Elbistan fly ash obtained by Eren and Nacar (2006) [43].

\section{Conclusion}

In this study, the differences between adsorption processes of Centaurea solstitialis (CS) and Verbascum Thapsus (VT) plants separately were compared for removal of Crystal Violet (CV) from aqueous solution. The experimental design was made by Surface Response Method (RSM) method; the model regression coefficients for CS and VT plants were 0.86 and 0.95 , respectively. Adsorption process for CS plant was fitted by D-R isotherm with the regression value of $R^{2}=0.9906$ and is suitable for pseudo-second-order kinetics $\left(\mathrm{R}^{2}=0.9998\right)$. For the VT plant, Temkin isotherm was found to have the highest regression value $\left(\mathrm{R}^{2}=0.9221\right)$ and was suitable for a pseudosecond-order $\left(\mathrm{R}^{2}=0.9999\right)$ kinetics. Adsorption processes of both plants with $\mathrm{CV}$ were endothermic. The maximum desorption rate for the CS and VT plants were $0.76 \%$ and $1.88 \%$, respectively. Based on these results, it was found that there was no dye recovery from both plants.

By comparison between the two plants, the VT plant might be preferred than the CS plant for the following reasons:

1. The maximum capacity of the VT plant was higher than the CS plant $(109.89 \mathrm{mg} / \mathrm{g}>84.03 \mathrm{mg} / \mathrm{g})$,
2. The contact time to reach the equilibrium capacity for the VT plant is shorter than the CS plant,

3. Change in calorific values for the VT plant was higher than the changes in the CS plant.

In this study, it has been proven that CS and VT plants are effective, inexpensive and easily available adsorbents in KV dye adsorption from aqueous solution. The calorific values of the dyed adsorbent materials obtained at the end of the adsorption were $4458.059 \mathrm{kcal}^{\mathrm{kg}}{ }^{-1}$ for CS and $4120.330 \mathrm{kcal}^{\mathrm{kg}}{ }^{-1}$ for VT. In other studies, the lower heat value of fuel produced from waste was found to be $2800 \mathrm{kcal}^{\mathrm{kg}} \mathrm{kg}^{-1}$ [47],[48]. According to these values, the dyed adsorbents can be used within the scope of waste derived fuel (ATY).

Cheremisinoff (2003) has reported that the waste can be converted to energy by incineration method, which is the second most frequent method [49]. Concerning that, the adsorption by-products could be used to generate energy by using it as a possible partial replacement of coal in the emission controlled industrial factories. Thus, many benefits will be achieved; CV will be removed from aqueous solution by lowcost materials, the adsorption by-products will be used as fuel, the uses of coal expected to be lower. In addition to that, the air pollution resulting from the raw plant burning process as a disposal method by the farmers will be decreased.

As a result from this study, the two plants (CS and VT) had been used successfully in CV removal from aqueous solution. Also the utilization of these plant in zero waste concept was achieved successfully.

\section{Acknowledgements}

The authors acknowledge the funding provided by the department of scientific research projects of Mersin University (Project Number: 2020-1-TP3-4010).

\section{Author contribution statements}

In the scope of this study, Mutlu YALVAÇ in the formation of the idea, the writing and editting, and the literature review; Hüdaverdi ARSLAN in the supplying the materials used; Mohammed SALEH in the formation of the idea, the writing and editing, the design and the literature review, Melis GÜN in the assessment of obtained results, and examining the results; Muhammed Sahin HEKIM in the experiment step in terms of content were contributed.

Table 7. Comparison with other studies.

\begin{tabular}{|c|c|c|c|c|c|}
\hline Adsorbent & Isotherm & Capacity (mg/g) & Kinetic Model & Thermodynamic & Reference \\
\hline Centaurea solstitialis (CS) & Dubinin-Radushkevich (D-R) & 84.03 & Pseudo-second-order & Endothermic & This study \\
\hline Verbascum thapsus (VT) & Temkin & 109.89 & Pseudo-second-order & Endothermic & This Study \\
\hline Palm fiber & Langmuir & $0,66^{*} 10^{-6}$ & Pseudo-second-order & Exothermic & {$[45]$} \\
\hline Centaurea stem & Langmuir & 476.19 & Pseudo-second-order & Endothermic & {$[46]$} \\
\hline
\end{tabular}




\section{Ethics committee approval and conflict of interest statement}

There is no need to obtain permission from the ethics committee for the article prepared.

There is no conflict of interest with any person / institution in the article prepared.

\section{References}

[1] Karataș M. Tekstil Boyalı Atık Suların Biyolojik Arıtımı. Doktora Tezi, Selçuk Üniversitesi, Konya, Türkiye, 2008.

[2] Kaykıoğlu G. "Kolemanit ve üleksit atiği ile sulu çözeltilerden metilen mavisi giderimi: kinetik ve izoterm değerlendirmesi". Celal Bayar Üniversitesi Fen Bilimleri Dergisi, 12(3), 499-509, 2016.

[3] Mevzuat Bilgi Sistemi. "Su Kirliliği Kontrolü Yönetmeliği". https://mevzuat.gov.tr/Metin.Aspx?MevzuatKod=7.5.72 21\&Mevzuatlliski=0 (16.11.2019).

[4] Canizo BV, Agostini E, Oller AL, Dotto GL, Vega IA, Escudero LB. "Removal of crystal violet from natural water and effluents through biosorption on bacterial biomass isolated from rhizospheric soil". Water, Air, \& Soil Pollution, 230(8), 1-14. 2019.

[5] Atlı B. Gıda Boyaları. Yüksek Lisans Tezi, Namık Kemal Üniversitesi, Tekirdağ, Türkiye, 2010.

[6] Abd-Elhamid AI, Fawal GF, Akl MA. "Methylene blue and crystal violet dyes removal (As a Binary System) from aqueous solution using local soil clay: kinetics study and equilibrium isotherms". Egyptian Journal of Chemistry, 62, 541-554, 2019.

[7] Yao W, Zhu W, Wu Y, Wang X, Jianati T. "Removal of crystal violet dye from wastewater by solidified landfilled sludge and its modified products". Polish Journal of Environmental Studies, 24(2), 777-785, 2015.

[8] Elella MH, Sabaa MW, ElHafeez EA, Mohamed RR. "Crystal violet dye removal using crosslinked grafted xanthan gum". International Journal of Biological Macromolecules, 137, 1086-1101, 2019.

[9] Moawed EA, Kiwaan HA, Elbaraay AA. "Synthesis and characterization of novel friendly biosorbents and it uses for removal of crystal violet dye from wastewater". International Journal of Scientific \& Engineering Research, 1(2), 1259-1278, 2019.

[10] Amuda 0, Amoo I. "Coagulation/flocculation process and sludge conditioning in beverage industrial wastewater treatment". Journal of Hazardous Materials, 141(3), 778-783, 2007.

[11] Benlin D, Tu X, Zhao W, Wang X, Leung DY, Xu J. "A novel three-dimensional heterojunction photocatalyst for the photocatalytic oxidation of crystal violet and reduction of Cr". Chemosphere, 211, 10-16, 2018.

[12] Greenlee LF, Lawyer DF, Freeman BD, Marrot B, Moulin P. "Reserve osmosis desalination: water sourses, technology, and today's challenges". Water Research, 43(9), 2317-2348, 2009.

[13] Lin SH, Lin CM. "Treatment of textile waste effluents by ozonation and chemical coagulation". Water Research, 1743-1748, 1993.

[14] Andreozzi R, Caprio V, Insola A, Marotta R. "Advanced oxidation processes (AOP) for water purification and recovery". Catalysis Today, 53(1), 51-59, 1999.
[15] Kurt E, Köseoğlu-Imer DY, Dizge N, Chellam S, Koyuncu I. "Pilot-scale evaluation of nanofiltration and reserve osmosis for process reuse of segregated textile dyewash wastewater". Desalination, 302, 24-32, 2012.

[16] Limenya. "Absorpsiyon ve Adsorpsiyon Arasindaki Fark". https://limenya.com/absorpsiyon-ve-adsorpsiyonarasindaki-fark/ (06.10.2019).

[17] Orbak İ. Aktif Karbon ile Çevre Kirletici Bazı Unsurların Giderilmesi. Doktora Tezi, İstanbul Teknik Üniversitesi İstanbul, Türkiye, 2009.

[18] Behara A, Mitra CJ. "Use of leaves and barks of some plants as bio-adsorbents in the control of methylene blue dye from waste water discharge of some industries". Journal of Chemistry and Chemical Sciences, 6(11), 1121-1136, 2016.

[19] Titi OA, Bello OS. "An overview of low cost adsorbents for copper (II) removal". Journal of Biotechnology and Biomaterial, 2015. doi: 104172/2155-952X.1000177.

[20] Sulyman M, et al. "Low-cost adsorbents derived from agricultural by-products/wastes for enhancing contaminant uptakes from wastewater: a review". Polish Journal of Environmental Studies, 26(2), 479-510, 2017.

[21] Reddy DHK, Vijayaraghavan K, Kim JA, Yun YS, "Valorisation of post-sorption materials: opportunities, strategies, and challenges". Advances in Colloid and Interface Science, 242, 35-58, 2017.

[22] Demir E, Yalçin H. "Adsorbentler: Sınıflandırma, özellikler, kullanim ve öngörüler". Türk Bilimsel Derlemeler Dergisi, $7(2), 70-79,2014$.

[23] Atıktan Türetilmiş Yakıt. "Ek Yakıt ve Alternatif Hammadde Tebliği". https://www.mevzuat.gov.tr/File/GeneratePdf?mevzuat No=19804\&mevzuatTur=Teblig\&mevzuatTertip $=5$ (16.11.2019).

[24] Saleh M, Yalvaç M, Arslan H. "Optimization of Remazol brilliant blue $r$ adsorption onto xanthium italicum using the response surface method". Karbala International Journal of Modern Science, 5(1), 55-63, 2019.

[25] Akay U. Tekstil Endüstrisindeki Atıksulardan Renk ve KOI Gideriminin Yanıt Yüzey Yöntemi ile Eniyilenmesi. Yüksek Lisans Tezi, Eskişehir Osmangazi Üniversitesi, Eskișehir, Türkiye, 2013.

[26] Gonzalez VH. "Bee visitors of centaurea solstitialis l. (asteraceae) in an urban environment in northwestern Turkey". Arthropod-Plant Interactions, 11(3), 403-409, 2017.

[27] Saleh M, Yalvaç M, Arslan H, Gün M. "Malachite green dye removal from aqueous solutions using invader centauera solstitialis plant and optimization by responce surface method: kinetic, isotherm, and thermodynamic study". European Journal of Science and Technology, (17), 755-768, 2019b.

[28] Ağaçlar.net. "Verbascum Thapsus". http://www.agaclar.net/forum/karadenizbolgesi/4980.htm (06.10.2019).

[29] Khamparia S, Jaspal DK. "Xanthium strumarium L. seed hull as a zero cost alternative for Rhodamine B dye removal". Journal of Environmental Management, 197, 498-506, 2017.

[30] Shakoor S, Nasar A. "Adsorptive decontamination of synthetic wastewater containing crystal violet dye by employing terminalia arjuna sawdust waste". Groundwater for Sustainable Development, 7, 30-38, 2018. 
[31] Massoudinejada M, Rasoulzadehb H, Ghaderpoori M. "Magnetic chitosan nanocomposite: fabrication, properties, and optimization for adsorptive removal of crystal violet from aqueous solutions". Carbohydrate Polymers, 206, 844-853, 2019.

[32] Johnson RD, Arnold FH. "The Temkin isotherm describes heterogeneous protein adsorption". Biochimica ET Biophysica Acta, 147(2), 293-297, 1995.

[33] Koçer 0. Zeytin Posası (pirina) Üzerine Malaşit Yeşili'nin Sulu Çözeltiden Adsorpsiyonu. Yüksek Lisans Tezi, Kilis 7 Aralık Üniversitesi, Kilis, Türkiye, 2013.

[34] Aniagor C, Menkiti M." Kinetics and mechanistic description of adsorptive uptake of crystal violet dye by lignified elephant grass complexed isolate". Journal of Environmental Chemical Engineering, 6(2), 2105-2118, 2018.

[35] Marco-Brown J, Guz L, Olivelli M, Schampera B, Sánchez RT, Curutchet G, Candal R. "New insights on crystal violet dye adsorption on montmorillonite: Kinetics and surface complexes studies". Chemical Engineering Journal, 10(2), 495-504, 2018.

[36] Zaidi NA, Lim LB, Usman A. "Artocarpus odoratissimus leaf-based cellulose as adsorbent for removal of methyl violet and crystal violet dyes from aqueous solution". Cellulose, 25, 3037-3049, 2018.

[37] Bezerra MA, Santelli RE, Oliveira EP, Villar LS, Escaleira LA. "Response surface methodology (RSM) as a tool for optimization in analytical chemistry". Talanta, 76(5), 965-977, 2008.

[38] Khan MMR, Rahman MW, Ong HR, Ismail AB, Cheng CK. "Tea dust as a potential low-cost adsorbent for the removal of crystal violet from aqueous solution". Desalination and Water Treatment, 57, 14728-14738, 2016.

[39] Mittal A, Mittal J, Malviya A, Kaur D, Gupta VK. "Adsorption of hazardous dye crystal violet from wastewater by waste materials". Journal of Colloid and Interface Science, 343, 463-473, 2010.

[40] Alizadeh N, Shariati S, Besharati N. "Adsorption of crystal violet and methylene blue on azolla and fig leaves modified with magnetite iron oxide nanoparticles". International Journal of Environmental Research, 11, 197-206, 2017.
[41] Sakin Omer 0, Hussein MA, Hussein BHM, Mgaidi A. "Adsorption thermodynamics of cationic dyes (methylene blue and crystal violet) to a natural clay mineral from aqueous solution between 293.15 and 323.15 K". Arabian Journal of Chemistry, 11, 615-623, 2018.

[42] Kulkarni MR, Revanth T, Acharya A, Bhat P. "Removal of crystal violet dye from aqueous solution using water hyacinth: equilibrium, kinetics and thermodynamics study". Resoure-Efficient Technologies, 3, 71-77, 2017.

[43] Eren F, Acar FN. "Adsorption of Reactive Black 5 from an aqueous solution: equilibrium and kinetic studies". Desalination, 194(1-3), 1-10, 2006.

[44] Mashkoor F, Nasar A, Inamuddin, Asiri AM. "Exploring the reusability of synthetically contaminated wastewater containing crystal violet dye using tectona grandis sawdust as a very low-cost adsorbent". Scientific Reports, 8, 8314, 2018.

[45] Alshabanat M, Alsenani G, Almufarij R. "Removal of crystal violet dye from aqueous solutions onto date palm fiber by adsorption technique". Journal of Chemistry, 2013. https://doi.org/10.1155/2013/210239

[46] Naderi P, Shirani M, Semnani A, Goli A. "Efficient removal of crystal violet from aqueous solutions with Centaurea stem as a novel biodegradable bioadsorbent using response surface methodology and simulated annealing: Kinetic, isotherm and thermodynamic studies". Ecotoxicology and Environmental Safety, 163, 372-381, 2018.

[47] Ayhan S. "Çimento sektöründe atıktan enerji geri kazanımı ve yasal mevzuat". 18 $18^{\text {th }}$ International Energy and Environmental Fair and Conference, İstanbul, Türkiye, 25-27 Nisan 2012.

[48] Ordu Ş, Öztürk E. "Çimento fabrikalarinda alternatif hammadde ve yakit kullanimi: örnek çalişma". Doğal Afetler ve Çevre Dergisi, 3(2), 87-92, 2017.

[49] Cheremisinoff NP. Handbook of Solid Waste Management and Waste Minimization Technologies. USA, ButterworthHeinemann, 2003.

\section{Appendix}

Appendix A.1. Sum of squares for the sequential model for CS plant.

\begin{tabular}{ccccccc}
\hline Source & Sum of Squares & df & Mean Square & F-value & p-value \\
\hline Mean vs Total & 94294.28 & 1 & 94294.28 & & $<0.0001$ & Suggested \\
Linear vs Mean & 12152.92 & 5 & 2430.58 & 43.88 & 0.0293 & A \\
2FI vs Linear & 1002.95 & 10 & 100.30 & 2.38 & 0.1069 & Aliased \\
Quadratic vs 2FI & 369.11 & 5 & 73.82 & 2.01 & & \\
Cubic vs Quadratic & 1059.77 & 16 & 66.24 & 156.56 & & \\
Residual & 5.50 & 13 & 0.4231 & & & \\
Total & $1.089 \mathrm{E}+05$ & 50 & 2177.69 & & & \\
\hline
\end{tabular}

Appendix A.2. Sum of squares for the sequential model for VT plant.

\begin{tabular}{ccccccc}
\hline Source & Sum of Squares & df & Mean Square & F-value & p-value \\
\hline Mean vs Total & 5085.86 & 1 & 5085.86 & & \\
Linear vs Mean & 48.24 & 5 & 9.65 & 59.36 & $<0.0001$ \\
2FI vs Linear & 1.56 & 10 & 0.1560 & 0.9486 & 0.5035 \\
Quadratic vs 2FI & 3.93 & 5 & 0.7866 & 13.75 & $<0.0001$ & Suggested \\
Cubic vs Quadratic & 1.62 & 16 & 0.1013 & 34.63 & & Aliased \\
Residual & 0.0380 & 13 & 0.0029 & & \\
Total & 5141.26 & 50 & 102.83 & & \\
\hline
\end{tabular}


Appendix B.2. ANOVA results for CCD during removal of CV by CS.

\begin{tabular}{|c|c|c|c|c|c|c|}
\hline Source & Sum of Squares & $\mathrm{df}$ & Mean Square & F-value & p-value & \\
\hline Model & 13155.87 & 15 & 877.06 & 20.79 & $<0.0001$ & significant \\
\hline A-pH & 2.25 & 1 & 2.25 & 0.0532 & 0.8189 & \\
\hline B-Mass & 4797.31 & 1 & 4797.31 & 113.71 & $<0.0001$ & significant \\
\hline C-Time & 331.41 & 1 & 331.41 & 7.86 & 0.0083 & significant \\
\hline D-Concentration & 6479.30 & 1 & 6479.30 & 153.58 & $<0.0001$ & significant \\
\hline E-Temp & 542.66 & 1 & 542.66 & 12.86 & 0.0010 & significant \\
\hline $\mathrm{AB}$ & 11.32 & 1 & 11.32 & 0.2684 & 0.6078 & \\
\hline AC & 2.79 & 1 & 2.79 & 0.0661 & 0.7987 & \\
\hline $\mathrm{AE}$ & 82.89 & 1 & 82.89 & 1.96 & 0.1701 & \\
\hline $\mathrm{BC}$ & 25.06 & 1 & 25.06 & 0.5940 & 0.4462 & \\
\hline BD & 311.33 & 1 & 311.33 & 7.38 & 0.0103 & significant \\
\hline $\mathrm{BE}$ & 156.47 & 1 & 156.47 & 3.71 & 0.0625 & significant \\
\hline CD & 23.68 & 1 & 23.68 & 0.5614 & 0.4589 & \\
\hline CE & 18.11 & 1 & 18.11 & 0.4292 & 0.5168 & \\
\hline $\mathrm{DE}$ & 359.57 & 1 & 359.57 & 8.52 & 0.0062 & significant \\
\hline Residual & 1434.38 & 34 & 42.19 & & & \\
\hline Pure Error & 0.0000 & 7 & 0.0000 & & & \\
\hline Cor Total & 14590.25 & 49 & & & & \\
\hline \multicolumn{7}{|c|}{ Appendix B.2. ANOVA results for CCD during removal of CV by VT. } \\
\hline Source & Sum of Squares & $\mathrm{df}$ & Mean Square & F-value & p-value & \\
\hline Model & 53.73 & 20 & 2.69 & 46.96 & $<0.0001$ & significant \\
\hline A-pH & 0.9100 & 1 & 0.9100 & 15.91 & 0.0004 & significant \\
\hline B-Mass & 25.08 & 1 & 25.08 & 438.39 & $<0.0001$ & significant \\
\hline C-Time & 1.10 & 1 & 1.10 & 19.21 & 0.0001 & significant \\
\hline D-Concentration & 21.19 & 1 & 21.19 & 370.39 & $<0.0001$ & significant \\
\hline E-Temp & 0.0235 & 1 & 0.0235 & 0.4115 & 0.5262 & \\
\hline $\mathrm{AB}$ & 0.0967 & 1 & 0.0967 & 1.69 & 0.2038 & \\
\hline $\mathrm{AC}$ & 0.0370 & 1 & 0.0370 & 0.6461 & 0.4280 & \\
\hline $\mathrm{AD}$ & 0.1919 & 1 & 0.1919 & 3.35 & 0.0773 & significant \\
\hline $\mathrm{AE}$ & 0.3055 & 1 & 0.3055 & 5.34 & 0.0282 & significant \\
\hline $\mathrm{BC}$ & 0.0295 & 1 & 0.0295 & 0.5159 & 0.4783 & \\
\hline CE & 0.0060 & 1 & 0.0060 & 0.1056 & 0.7476 & \\
\hline DE & 0.0024 & 1 & 0.0024 & 0.0422 & 0.8386 & \\
\hline$A^{2}$ & 0.2559 & 1 & 0.2559 & 4.47 & 0.0432 & significant \\
\hline $\mathrm{B}^{2}$ & 2.24 & 1 & 2.24 & 39.10 & $<0.0001$ & significant \\
\hline$C^{2}$ & 0.8592 & 1 & 0.8592 & 15.02 & 0.0006 & significant \\
\hline$D^{2}$ & 0.0673 & 1 & 0.0673 & 1.18 & 0.2870 & \\
\hline$E^{2}$ & 0.0078 & 1 & 0.0078 & 0.1369 & 0.7141 & \\
\hline Residual & 1.66 & 29 & 0.0572 & & & \\
\hline Lack of Fit & 1.66 & 22 & 0.0754 & & & \\
\hline Pure Error & 0.0000 & 7 & 0.0000 & & & \\
\hline Cor Total & 55.39 & 49 & & & & \\
\hline
\end{tabular}

